\title{
РОДОВЫЕ УГОДЬЯ БЕЗ РОДОВИКОВ - ОТРАЖЕНИЕ ПОЛИТИКИ ТРАДИЦИОННОГО ПРИРОДОПОЛЬЗОВАНИЯ (НА ПРИМЕРЕ ЗАПАДНЫХ РАЙОНОВ ХМАО-ЮГРЫ)
}

Земельное право коренных народов в Югре возникло в противовес нефтегазовому освоению и растущему отчуждению земель. Принятое в 1992 г. Положение о статусе родовых угодий расиенивалось как юридическая основа для поддержки традиционного природопользования и идентичности хантов и манси. Наибольшее распространение угодья получили в центральных и восточных районах округа, где проживали хантьл. В западных районах, где проживали манси, родовые угодья не получили широкого распространения, и статья объясняет причины этого дисбаланса. На примере Кондинского и Березовского районов описана экономическая и этническая обстановка, определившая отличие западных районов от восточных; показаны специфические проблемы выделения родовых угодий, разные решения администраций, отдельно разобран случай родовиков села Болчары. Современное состояние родовых угодий описано на основе наблюдений, интервью с владельцами, а также на материалах функиионального зонирования территорий традиционного природопользования ХМАО-Югры. Статья характеризует юридическо-экономический контекст, в котором родовые угодья существуют четверть века, иллюстрируя постепенное выхолашивание изначальной идеи из-за изменений законодательства. Показано расхождение между кониепџией традиционного природопользования как задачи по самообеспечению индигенных домохозяйств и реалиями рыночной экономики, которые требуют ведения товарного хозяйства или внешних источников дохода. Родовые угодья стали дорогим инвестиционным проектом с непонятным целеполаганием. Большая часть наследственных владельцев не может или не знает, как использовать земли.

Ключевые слова: родовье угодья, территории традиционого природопользования, коренные народы, общины, хантыл, манси, неотрадиционализм

Ссылка при цитировании: Абрамов И.В. Родовые угодья без родовиков - отражение политики традиционного природопользования (на примере западных районов ХМАО-Югры) // Вестник антропологии, 2021. № 2. С. 324-339.

Абрамов Илья Викторович - научный сотрудник, Институт истории и археологии УрО РАН (620108 Екатеринбург, ул. Софьи Ковалевской, 1б). Эл. почта: ilya_abramov@list.ru 
Первая нефть Западной Сибири была обнаружена около мансийской деревни Шаим на Конде в 1959 г., но самые богатые месторождения чуть позже были открыты на землях восточных хантов. В Сургутском и Нижневартовском районах добывающая промышленность создала обширную сеть дорог и трубопроводов поверх оленьих пастбищ и рыбных водоемов, загрязнив огромные площади. Поскольку нефтедобыча была абсолютным приоритетом развития, нефтяники свободно распоряжались землей и «нарезали» месторождения, как им вздумается, игнорируя хозяйство народов Севера. Площадь непригодных и недоступных для оленеводства и промыслов земель неуклонно росла, лишая народы Севера основы существования. Катастрофическое положение народов Среднего Приобья стало предметом особого внимания во время Перестройки. В 1989 г. 33\% территории округа зарезервировали под земли приоритетного природопользования, исключив там добычу и разведку углеводородов, но не существовало правового механизма, который бы позволил закрепить эти земли за хантами и манси ${ }^{1}$. Разработка профильного закона заняла три года и в 1992 г. Положение о родовых угодьях было принято, став первым подобного рода документом в Российской федерации. Коренные народы Югры добились права получать землю в пожизненное наследуемое владение, общины - в бессрочное пользование или аренду. Родовые угодья - естественно-природный комплекс территорий (леса, реки, их берега, озера, болота, луга, пастбища и др.), на которых исторически сложились образ жизни и формы традиционного хозяйствования коренных жителей Ханты-Мансийского автономного округа (Положение... 1992: 2).

К 1999 г. было выделено 465 родовых угодий, занявших 55\% Сургутского района, 49\% Нефтеюганского и 25\% Нижневартовского (Пахомов и др. 2000: 9). Это были земли исторического проживания хантов. В наиболее пострадавшем от нефтяников Сургутском районе угодий отвели на $10 \%$

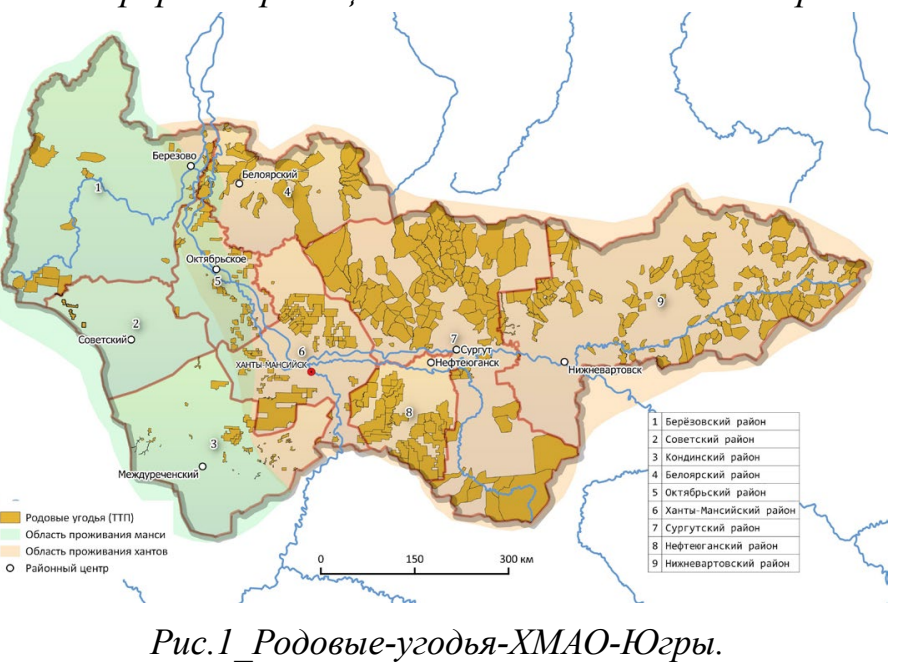

Pис.1_Pодовые-угодья-ХМАО-Югрыл.

больше, чем было предусмотрено лимитом. На западе, в Кондинском и Березовском районах (где жили преимущественно манси) угодья заняли 3,3 и 16,4\% площади соответственно, лимит был выбран в первом случае на $10 \%$ (0,2 тыс. га), во втором на 50\% (1,4 тыс. га). Разница Сургутского и Кондинского районов по площади выделенных угодий оказалась тридцатикратной (рис. 1). Чтобы объяснить причины столь разной практики отведения родовых угодий следует охарактеризовать западные районы: исходные условия, политику администраций и землепользователей, ожидания и возможности заявителей. Это позволит понять, почему меры по развитию традиционного природопользования в ХМАО-Югре не достигают цели.

\footnotetext{
1 Закон Ханты-Мансийского автономного округа - Югры от 9 августа 1989 года № 116 «Об образовании территорий приоритетного природопользования».
} 


\section{Историография и методы}

Термин «традиционное природопользование» оформился на рубеже 19801990-х гг. в дискуссиях о путях возрождения коренных народов. Самой заметной стала концепция неотрадиционализма, призванная объединить самобытные ценности и институты народов Севера с технологическими, экономическими и экологическими новациями (Пика, Прохоров 1994). Общины коренных народов виделись главными субъектами новой северной политики и экономики, общинные земли в статусе ТТП должны были укрепить их самостоятельность.

Вокруг коренных малочисленных народов Севера (КМНС) сложилось особое дискурсивное поле и риторика традиционности (Кучинский 2007). Самобытные хозяйственные практики признали «неистощительными» для природы, что было закреплено в федеральном законе о территориях традиционного природопользования (далее - ТТП) в 2001 г. Однако понятия «традиционный образ жизни», «исконная среда обитания» остались уязвимыми для критики, поскольку не поясняли, какой период берется за точку отсчета традиции. В свою очередь, правоприменение по этническому признаку породило массу коллизий, особенно в регионах масштабного хозяйственного освоения, таких как Ханты-Мансийский автономный округ, где доля коренного населения в течение XX в. сократилась до $2 \%$, а смешанные браки преобладали.

Натуральную экономику коренных народов в постсоветский период фиксировали этнографы (Мартынова 2017, 2019; Пивнева 2019) и социологи (Харамзин 2001; Хакназаров 2016). В ряде случаев исследования были регулярными, например, коренных жителей четырех западных районов опрашивали каждые два года с 1993 по 1999 гг;; это позволило выявить динамику мнений по вопросам традиционного природопользования (Харамзин, Хайруллина 2000). Нюансы фактического использования родовых угодий в Ханты-Мансийском и Октябрьском районах описали Е.П. Мартынова и Е.А. Пивнева (1999). Правовые аспекты функционирования родовых угодий антропологически разбирала Н.И. Новикова (Новикова 2008: 16-38; Новикова 2014: 114-176). Экономисты также обращались к проблемам коренного населения ХМАО, оперируя статистикой на уровне макрорайонов и регионов (Куриков 2012; Логинов 2003). При всем обилии работ, посвященных традиционному природопользованию коренных народов, крайне мало публикаций, касающихся конкретных случаев и людей; родовые угодья редко становились предметом отдельного исследования. Уровень домохозяйств антропологами рассматривался лишь однажды, осветив состояние промыслов и экономику угодий хантов в переходные времена (Buгет 2002).

Данная работа опирается на полевые наблюдения и интервью, архивные документы и статистику. С 2001 г. родовые угодья официально называются территориями традиционного природопользования, их владельцы - субъектами права ТТП. Сами себя они по-прежнему именуют родовиками, подчеркивая первоначальный замысел проекта. Экономически активные родовики Березовского и Кондинского районов стали основными информантами по теме, также были опрошены ответственные специалисты районных администраций. В департаменте недропользования и природных ресурсов ХМАО-Югры (Ханты-Мансийск) были получены важные для анализа атласы зонирования территорий традиционного природопользования. Таким образом, полевые наблюдения были проверены на камеральных данных, что позволило прийти к взвешенных выводам. 


\section{Березовский район}

Северо-запад Ханты-Мансийского округа занимает Березовский район, небогатый углеводородами. Поселения района связывают реки, автодороги не развиты, выезд на региональные трасы возможен только зимой. Транспортная изоляция обеспечила сохранность промысловых угодий - лучших по соболю, лосю и северному оленю в Югре. В 2010 г. в Березовском районе проживало 70\% сельских манси. В результате коллективизации, оседания и укрупнения они стали жителями больших полиэтничных поселков, нигде не образуя уверенного большинства. Это существенно отличало их от хантов: в Сургутском районе множество семей по-прежнему жило на стойбищах (одна-две семьи), занимаясь оленеводством. Именно семейные пастбища хантов стали приоритетной базой для оформления родовых угодий в наследуемое владение в 1990-е годы. У манси оленей в частном владении практически не осталось, поэтому общинные родовые угодья на базе охотничье-рыболовных участков выглядели здесь более подходящим вариантом. Из 66 арендованных по округу родовых угодий, 29 находились в Березовском районе, ни одного в Сургутском, Нефтеюганском, Нижневартовском районах (Территория... 2004: 42).

До конца 1993 г. в Березовском районе было организовано 14 родовых угодий, из них 6 оформлены на общины, 8 - на индивидуальных пользователей (ААБР: Ф. 72. Оп. 1. Д. 14. Л. 41). Общинные угодья стали самыми большими в ХМАО. Их выделяли из фонда Березовского коопзверопромхоза (КЗПХ), которому принадлежала почти вся земля, покрытая лесом. Аналогичным образом рыбугодьями района заведовал Березовский рыбкомбинат. Это были стабильно работающие предприятия, с отделениями во всех таежных поселках: охотникам выделялись охотничьи участки, оружие, стройматериалы, в отдаленные места доставляли на вертолетах. Такая работа не подвигала к мысли о родовом угодье, где все пришлось бы делать самому. Но этнические активисты считали, что при целевой поддержке ханты и манси смогут создать лучшие условия жизни на родовых угодьях, особенно объединившись в общины. На последние возлагались особые надежды, как на формы сельского самоуправления, которые заменят сельсоветы.

Получив в аренду земли, общины района столкнулись с тем, что условия пользования биоресурсами по-прежнему определяет Березовский коопзверопромхоз, который остался безальтернативным агентом по предоставлению лицензий на пушного зверя и скупке шкур, а поддержка окружных фондов незначительна. Когда в 2000 г. у многих закончились сроки аренды родовых угодий, Березовский КЗПХ препятствовал их перезакреплению (ААБР: Ф. 72. Оп. 1. Д. 44. Л. 6). Общины так и не получили прав распоряжаться биоресурсами, что на фоне рухнувшей торгово-закупочной сети и цен обессмысливало экономику родовых владений. Из шести общин лишь опыт «Кимкъясуя» можно считать успешным, хотя в конечном итоге и она распалась, не выдержав рыночных скачков и внутренних конфликтов (Федорова 2012).

Местная тайга не знала семейного-родового права на ресурсы, но была знакома с межэтническими конфликтами за промысловые угодья. Березовский район отличался самой высокой в округе напряженностью между аборигенным и иноэтничным населением, что отметил каждый второй опрошенный в 1997 г. (Харамзин, Хайруллина 2000: 10). С помощью родовых угодий некоторые заявители рассчитывали ограничить доступ нестатусных (не КМНС) соседей, о чем не стеснялись говорить. На одном из совещаний у главы района, где в споре об угодьях сошлись разные стороны, сосьвин- 
ский охотовед не выдержал: «Вы что хотите второго Карабаха!» (интервью, п. Сосьва, 2016). Это был один из веских доводов для замораживания заявок на родовые угодья.

Исходя из формальных критериев (обилие земель, высококлассные угодья, высокий удельный вес коренного населения, поддержка этноактивистов), казалось, что Березовский район может и должен обеспечить свободу хозяйствования аборигенов, но на деле выходило, что родовые угодья пришлись не к месту и не ко времени.

\section{Кондинский район и случай села Болчары}

Район соответствует бассейну Конды - области проживания южных хантов и манси, отличающихся языком и культурой от северных групп. Вокруг каждой деревни были закрепленные за ней лесные и водные угодья, которые использовались сезонно под разные промыслы. Особое значение для общин имел запорный рыбный промысел на Конде и притоках, требующий коллективных действий для создания и обслуживания заграждений. В начале XX в. заготавливали столько рыбы и ягод, чтобы вести выгодный торг с соседями, выменивать рыбу на муку и мануфактурные товары.

В 1930-е гг. угодья были национализированы в пользу колхозов и артелей, село Болчары стало центром укрупнения деревень и юрт. Чуть позже - центром лесозаготовок, испытав приток рабочей силы из других регионов. Численность села относительно 1926 г. за полвека выросла более чем в 10 раз, достигая на пике 2,5 тыс. человек. В настоящее время в селе проживает около 2 тыс. человек, 700 из них имеют статус КМНС ${ }^{1}$. Местные диалекты полностью утрачены, национальные черты нивелированы. Профильные законы по защите и поддержке КМНС в 1990-е гг. спровоцировали смену паспортной идентичности, которая на Конде приобрела особый масштаб и расценивалась почти исключительно как доступ к льготам.

Теоретически институт родовых угодий позволял вернуть себе угодья предков, но по факту район оказался одним из аутсайдеров в деле выделения угодий, а их размер был наименьшим. За 8 лет с 1992 г. было оформлено 35 родовых угодий, из них 6 - на общины. Чаще всего просили в пользование несудоходные притоки Конды с подходящими для рыболовства условиями, поэтому очертания угодий во многих случаях повторили линию водоемов. Самым маленьким родовым угодьем Кондинского района и всего округа стала протока (пойменный ручей) с 15-метровой водоохранной зоной, площадью 6,7 га, которую пересекает оживленный автозимник. Угодье-ручей юридически существует до сих пор без всяких признаков его использования по назначению.

В Болчарах с 1993 по 1999 гг. родовые угодья отвели пять жителей села. 11 января 1993 г. первым землю под общину «Выгиль» оформил Нялин Николай. Старые угодья хантов Нялиных были по рекам Хешма и Сёртым в левобережье Конды, но Николай выбрал Выгильский Сор, который до национализации был в общем пользовании местных хантов, а в советское время стал одним из лучших водоемов болчаровского колхоза «40 лет Октября». Комиссию это не смутило и заявку одобрили. На следующий год колхоз отвоевал озеро назад, добившись аннулирования решения комиссии. Тогда Нялин обратился к В.А. Чурилову - депутату РСФСР, бывшему первому секретарю окружкома, и угодье вновь передали ему. Сам Выгильский Сор при этом остался водоемом для промышленного лова, и право промысла рыбы в нем может получить стороннее предприятие, но воспользоваться им сможет только с согласия Нялина.

\footnotetext{
${ }^{1}$ Данные администрации Болчаровского сельского поселения.
} 
Александр Кобылин оформил родовое угодье через три месяца после Нялина, на подведомственной земле - он возглавлял Болчаровский участок Кондинского коопзверопромхоза. Через год оформил угодье Владимир Бельский, также занимавший управленческую должность в Болчарах. Наблюдая за их успехами и собственной застрявшей заявкой, рыбак Анатолий Б. в 1994 г. обратился в окружную ассоциацию коренных народов «Спасение Югры», где обозначил специфику поселка, где из четырех владельцев родовых угодий, «националом является только Нялин, а остальные по национальности русские, все приезжие» (ГАХМАО: Ф. 418. Оп. 1. Д. 51. Л. 18).

Несколько лет длилось затишье, и новый всплеск активности случился лишь в конце 1990-х гг. Хантыйский рыбак Георгий Сургучев получил добро на рыболовный участок по реке Чепыш, где рыбачил от колхоза. В 1998-1999 гг. вместе со взрослым сыном Николаем он объехал Междуреченский, Ханты-Мансийск, Тюмень, добился встречи с окружным главой А.В. Филиппенко, чтобы продвинуть заявку, которая застряла в кабинетах. Усилия не прошли даром, и угодье было отведено. Последним в Болчарах в июне 1999 г. получил угодье русский Владимир Брусков, возглавлявший в разные годы колхоз и сельсовет.

Заключим: рядовой промысловик мог добиться родового угодья, приложив организационные усилия и проявив настойчивость, но его путь был значительно дольше и извилистее, чем у руководителей предприятий и органов власти, обладавших связями и информацией. Во всех случаях заявителей прежде всего интересовали богатые рыбой водоемы, где уже имелась инфраструктура лова. Работа с заявками была непрозрачной: в игнорировании проблем кондинскую комиссию обвиняла активистка и член «Спасения Югры» Ольга Александровна Кошманова (ГАХМАО: Ф. 418. Оп. 1. Д. 57. Л. 27). Чиновники, в свою очередь, перекладывали вину на землепользователей, которые тянули с согласованием отводов. По опросу 1995 г. в западных районах округа на одного получившего угодья приходилось четверо желавших это сделать; четверть опрошенных заявили, что в угодьях не нуждается (Харамзин, Хайруллина 2000: 93).

\section{От родовых угодий к ТТП}

Положение о родовых угодьях действовало до 2001 г., когда был принят федеральный закон «О территориях традиционного природопользования коренных малочисленных народов Севера, Сибири и Дальнего Востока РФ». Закон исключал право пожизненного наследуемого владения землей, которое было прописано в актах выдачи родовых угодий. В возникшем правовом вакууме округ постановил признать родовые угодья территориями традиционного природопользования регионального значения. Это решение опережало реальность, так как требовалось установить правовой режим, а для этого провести зонирование и законодательно закрепить границы - работа, которая растянулась на много лет. В этой ситуации югорские власти выступили гарантами земельных прав коренных народов перед недропользователями, утвердив родовые угодья в статусе ТТП, минуя ряд положенных федеральным законом процедур. В какой-то момент «...единственным юридическим документом, подтверждающим существование аборигенов на их землях, стали экономические соглашения с нефтяниками» (Новикова... 2008: 28). 
В 2006 г. был принят окружной закон о территориях традиционного природопользования регионального значения, где утверждалась процедура их создания, но последовавший за ним Лесной кодекс лишил Югру права создавать ТТП, поскольку лес стал федеральным. Работа сосредоточилась на урегулировании статуса существующих ТТП: создали реестр, куда стали вписывать родовиков как субъектов права, запланировали зонирование земель ${ }^{1}$.

С 2002 г. число ТТП не менялось - 475. Контраст в площадях и количестве субъектов ТТП между западными и восточными районами сохранился и даже усилился. При переходе от родовых угодий к ТТП, требовалось подтверждение собственников: из 41 родовых угодий Кондинского района 6 владельцев так и не объявились, и реестр сократился до 35 (интервью, чиновник, г. Междуреченский, 2018). К 2008 г. на родовых угодьях Кондинского и Березовского районов проживало менее 50 человек, 1-3\% общего числа коренных жителей районов, в то время как в Сургутском районе почти 2 тыс. чел. - 78\% аборигенов района (Логинов 2008: 82).

Первые проекты положений о правовом режиме ТТП были приняты Правительством округа только в 2016 г., по результатам функционального зонирования угодий в Нижневартовском и Сургутском районах (Функциональное... 2012). Таким образом, прошло почти пятнадцать лет с момента обсуждения необходимости разработки правовых режимов ТТП до принятия первых десяти из них ${ }^{2}$. Все это время они де факто находились вне правовых рамок.

\section{Режим пользования территориями традиционного природопользования}

В 2015 г. дошла очередь до зонирования территорий традиционного природопользования Белоярского, Березовского, Кондинского, Нефтеюганского, Октябрьского, Советского и Ханты-Мансийского районов ХМАО-Югры (Функциональное..., 2015) ${ }^{3}$. Главным итогом работ являются карты, отражающие биоресурсы ТТП и промысловую инфраструктуру. Подсчитаны площади и продуктивность природных комплексов по оленеводству, охоте, сбору дикоросов. Родовики помогали составлять паспорта ТТП, обозначая места сбора и добычи биоресурсов, недвижимые объекты, границы. Оценивались не конкретные результаты их промыслов, а ландшафтно-ресурсный потенциал угодий. Насколько родовики пользовались этим потенциалом, не указано. Недостатком отчетов является полное отсутствие какой-либо аналитики, выводов и рекомендаций. Опросы родовиков также не включены. Количественные данные сведены в таблицы, для обоснования выделения трех типов функциональных зон: строгого охранного режима, обычного режима, ограниченного хозяйственного использования.

В контексте статьи самым важным является раздел «Подтверждение факта проживания и ведения традиционного образа жизни» (Функциональное..., 2015: 4849). Родовики были выделены в три группы: кто ведет традиционный образ жизни,

${ }^{1}$ Актуальная информация по ТТП и субъектам права, их национальному составу: Хакназаров, 2016, c. 21.

2 Постановление Правительства ХМАО - Югры от 3 ноября 2016 г. № 432-п «Об утверждении положений о правовом режиме территорий традиционного природопользования коренных малочисленных народов Севера регионального значения в Ханты-Мансийском автономном округе - Югре №№ HB-B32, НВ-B34, НВ-К13, НB-К18, НB-О22, С-8Л, С-7У, С-2P, С-16С, С-14Л».

3 Отчеты хранятся в Департаменте недропользования и природных ресурсов ХМАО-Югры. Предоставлены автору в электронном виде по официальному запросу от организации. 
проживая на ТТП (1 группа), кто проживает в сельской местности, но традиционная хозяйственная деятельность не является основной (2 группа); 3-я группа - горожане, эпизодически появляющиеся на ТТП. В таблице 1 выбраны данные по четырем западным районам, обсуждаться на основе собственных полевых материалов будут только случаи Кондинского и Березовского районов.

Таким образом, в 2014 г. из 6378 представителей КМНС Березовского района ${ }^{1}$ на родовых угодьях постоянно проживало 28 человек $(0,4 \%)$, что подтверждается полевыми наблюдениями. Порядка 70 человек пользовались угодьями как промысловыми участками для охоты или рыболовства. Полных семей, постоянно живущих на угодьях, было три: Савелия Самбиндалова (Юрты Турват, 9 человек), Андрея Пакина (3 человека), Алексея Новьюхова (Юхонгорт, 3 человека). Только в их случаях родовые угодья - основное или единственное место проживания.

Таблица 1

Характер проживания на ТТП ХМАО-Югры

\begin{tabular}{l|l|l|l|l|l|l|l}
\hline Район & ТТП & Семей & Чел. & Из них, КМНС & $\mathbf{1}$ гр. & $\mathbf{2}$ гр. & 3 гр. \\
\hline Березовский & 21 & 29 & 99 & 95 & 28 & 59 & 12 \\
\hline Кондинский & 35 & 50 & 147 & 119 & 10 & 32 & 105 \\
\hline Белоярский & 34 & 90 & 335 & 312 & 37 & 238 & 49 \\
\hline Октябрьский & 54 & 67 & 190 & 117 & 9 & 80 & 101 \\
\hline
\end{tabular}

В Кондинском районе из 5136 представителей КМНС ${ }^{2}$ на родовых угодьях постоянно проживало 10 или менее человек $(0,2 \%)$, ни одной полной семьи. Сезонно посещали угодья 137 человек, при этом 105 их них - жители городов. Если детализировать третью группу, то порядка $60-70 \%$ окажутся потомками и родственниками владельца, не связанные с тайгой и промыслами. По 6-8 месяцев в году на угодьях жили только рыбаки, присматривающие за рыболовными ловушками. Обычно это одинокие мужчины, односельчане владельца угодий. Именно эти люди на регулярной основе занимались традиционным природопользованием, в то время как владелец решал организационные вопросы в поселке.

Похожая картина наблюдалась в 1999 г. в Октябрьском районе. Из пятидесяти владельцев родовых угодий на территории проживал только один, остальные навещали их эпизодически, используя как дачи (Мартынова, Пивнева 1999: 16). Данные зонирования 2015 г. говорят об этом же, только “дачников”, вероятно, стало еще больше, поскольку уровень благосостояния селян в 2000-х гг. вырос. До этого опросы показывали крайне низкую обеспеченность коренного населения лодками, снегоходами, автомототранспортом и бензопилами. В 1997 г. моторку и бензопилу имел лишь один из четырех, снегоход или мотоцикл - один из десяти, и каждый десятый не имел ничего из перечисленного (Харамзин, Хайруллина 2000: 91). Угодья не освоить при таком уровне благосостояния - даже поддерживать имеющуюся инфраструктуру затруднительно. Поэтому для многих родовые угодья так и остались запасным вариантом на случай прихода нефтяников.

\footnotetext{
${ }^{1}$ Данные Березовской администрации за 2014 г

2 Данные Кондинской администрации за 2014 г.
} 
На Конде дачный вариант характерен примерно для трети угодий. Особенно это касается "пригородных" владений, связанных дорогами с крупными населенными пунктами. Такая жизнь немыслима без нескольких видов транспорта, обустроенной усадьбы, бензотехники, электричества, современных средств связи, то есть без устойчивых “внеусадебных" источников дохода. По данным опроса 2015 г. основными источниками дохода родовиков являлись заработная плата (50,1\% опрошенных) и продажа биоресурсов (49,1\%), на третьем месте $(33,6 \%)$ выплаты социальных фондов (Хакназаров 2016: 49-50). Не связанный с биоресурсами источник дохода, позволял инвестировать в инфраструктуру угодья, превращая минималистичный промысловый стан в комфортабельное жилье, и делая его пригодным для приема гостей и туристов. Необходимость работать в поселке, отвозить детей (внуков) в школу, привела к распределенному образу жизни, который не сочетаем с традиционным укладом.

Поселковые жители привыкли мозаично использовать окрестности: рыбалка в одном месте, сбор ягод в другом, сенокос - в третьем, наличие родового угодья подразумевало, что теперь все промыслы умещаются внутри. Это работает на больших угодьях стойбищных хантов (Buгет 2002). Для поселковых же родовиков угодья стали дополнительным, и зачастую необязательным вариантом жизнеобеспечения. Малый размер кондинских угодий в принципе говорил о моноресурсной направленности и сезонности. Границы на местности размечали крайне редко - это требовались только в случае промышленных работ и земельных конфликтов.

Вернемся в Болчары. Николай Нялин до 2015 г. использовал родовое угодье под промысел рыбы, добывая по 30-60 т в год запорами. 80\% угодья занимает Выгильский сор. Основной сезон лова ноябрь-январь, готовиться к нему начинают летом, остальное время года угодье пустует, твердой дороги туда нет. В 2016 г. Нялин перестал запирать вытекающую из озера речку. Разведение крупного рогатого скота оказалось более выгодным и предсказуемым делом, чем рыба, с которой возникало много проблем, решение которых не зависело от Николая. Животноводством Нялин занялся в родной д. Чеснок на Конде, за пределами ТТП. Однако в 2019 г. он забил весь скот и теперь делает ставку на развитие туризма на берегу Выгильского сора - его обнадежил опыт приема богатых рыбаков и окружная субсидия на строительство гостевых домиков.

Отставной начальник пожарной службы Александр Кобылин имеет отдаленное, труднодоступное родовое угодье, куда дорога из Болчар занимает 8-10 часов: либо лодкой, либо лодкой и болотоходом, в первом случае требуется 100 литров топлива в оба конца, не считая погнутых винтов, во-втором - спецтранспорт, который появился в хозяйстве недавно. Снегоходная дорога, напротив, занимает не более трех часов, и зимний период - главный для угодья. Кобылин считает содержание угодья невыгодным, даже с учетом приема туристов-рыбаков, которые инвестируют в его озерные базы. Раньше он также занимался запорным ловом, но уже много лет не закрывает речки по причине несоответствия затрат и прибыли. На угодье он бывает наездами, в остальное время за хозяйством присматривают родственники и наемные работники.

Николаю Сургучеву до родового угодья два часа езды на лодке и автомобиле. На p. Чепыш он до сих пор занимается запорным ловом «на прокорм», хотя его река обеспечивала промышленные объемы добычи в советские годы. Николай унаследовал промысловый стан от отца, рыбачившего на колхоз, сам большую часть жизни отработал водителем в нефтянке. В делах помогает зять, но главный работник угодий - бездомный друг, живущий на угодье постоянно. 
Все упомянутые родовики уже пенсионеры, и могут себе позволить пожить на угодье летом «для души», «как предки». Если же дело касается присмотра за промыслом, вроде запорного лова, как правило, ищут одинокого работника. Прямые наследники редко связывают свою жизнь с традиционным природопользованием. Так случилось с угодьями Бельского и Брускова, которые пустуют уже много лет.

\section{Вопреки правилам}

С 2005 г. родовиков стали официально именовать субъектами права ТТП, а шефство после упразднения Департамента по делам КМНС, взял департамент недропользования (сейчас - департамент природных ресурсов и несырьевого сектора экономики). Как мудро заметил один родовик: «Теперь волки караулят овец». Редактирование всех основных документов, касающихся природных ресурсов, привело к тому, что родовик ограничен в правах по сравнению с 1990-ми гг. Федеральную древесину отводит лесник, окружных зверя и рыбу по квотам выделяет окружной центр. За все предоставленные ресурсы надо регулярно отчитываться, даже если они не были востребованы.

По закону на каждого члена семьи или родовой общины, положено 300 кг рыбы в год, что едва покрывает уровень физического потребления. «За месяч холодов собака съедает 300 кг, а тут человеку на год! Как они считали?» (интервью, Вахрушев Е.А., родовик, председатель общины, д. Карым, 2017). Все что сверх лимита, считается промышленным ловом. Это тянет за собой бухгалтерскую отчетность, юридический адрес, наемных сотрудников, промысловый участок, выигранный на аукционе и пр. Организация товарного лова рыбы сразу превращает родовика в менеджера, который должен быть всегда на связи, в поселке. И поскольку соблюсти норму в 300 кг невозможно, все родовики в глазах проверяющих органов становятся браконьерами. На деле никто больше родовика не заинтересован в поддержании биоразнообразия и животных ресурсов, чем он сам. Родовик вовремя уберет рыболовный запор на реке, потому что иначе надолго лишится рыбы, - он знает меру, и она и заметно больше 300 кг на человека.

К институционализации промыслов и образованию национальных предприятий в начале 2000-х гг. активно подталкивали с помощью субсидий на промышленный лов, льготного налогообложения и прямых уговоров. Но, несмотря на программы переоснащения, все национальные предприятия округа (80\% которых сосредоточены в западных районах) официально не выбирали даже половины предоставленной им рыболовной квоты (Территории... 2005: 37). Из этого факта управленцы Ханты-Мансийска сделали вывод, что деятельность КМНС «направлена в основном на обеспечение собственных потребностей», и в 2006 г. субсидии передали рыбозаводам. Рыболовные безземельные общины сразу рухнули, а родовики переориентировались на рыночных агентов.

В 2002 г. из девятнадцати действующих общин Березовского района родовые угодья были у десяти. Некоторые из них работают до сих пор. На угодьях ляпинской общины «Турупья» сезонно промышляют 22 охотника-соболятника. Сосьвинская община «Рахтынья» несколькими бригадами промышляет ценную проходную рыбу по Северной Сосьве и Ляпину, ее главный рыболовный стан расположен на родовом угодье, а прилегающий рыбопромысловый участок на р. Ляпин берется в аренду. В 
Кондинском районе рыболовством занимаются общины «Карым» и «Киндаль», как на родовых угодьях, так и на водоемах для промышленного лова. Другими словами, связка родового угодья и общины при должном подходе обеспечивает существование “традиционного хозяйства", но само по себе оно малорентабельно. «Проще было бы рыбу официально не показывать и не ловить <... > Но приходится, чтобь люди работали. Работа ради работь» (интервью, председатель общины, Березовский район, 2016). Организация родовиками общин, фермерских хозяйств, ИП, с предоставлением рабочих мест - социальная, в сущности, миссия, не имеющая прямого отношения к рынку. Сочетание формального и неформального в традиционной экономике подтверждается множественными наблюдениями (Мартынова 2019: 78). Родовики и общинники существуют в обоих измерениях, чтобы выжить самим и дать работу другим.

Родовику-общиннику желательно обрасти другими земельными и безземельными активами, чтобы стать устойчивым и независимым. Владелец угодья должен постоянно “крутиться”: брать по соседству перспективные рыбопромысловые и охотничьи участки, заявляться за гранты по туризму, играть “по правилам” чиновников и без них. Например, сдавать соболя по дотации невыгодно, так как цена ниже рыночной, но эта система позволяет оставаться в легальном поле, получать охотничьи лицензии и претендовать на другие виды помощи, в частности, компенсировать 50-75\% стоимости снегоходов, боеприпасов, сетей и стройматериалов. Наличие программ поддержки удерживает некоторые хозяйства в белом сегменте экономики, другие не готовы мириться с бумагооборотом и лишними поездками, и уходят в “тень”, навсегда исчезая для статистики. Они смотрят на тех родовиков и общинников, кто “не справился” с субсидией и оказался под судом - риск подобного исхода довольно велик, потому что крайне сложно соблюсти все правила.

Только в товарной форме официальное “традиционное природопользование” сегодня имеет смысл, но натыкается на старые проблемы отрасли: слаборазвитую торгово-закупочную сеть (факторий), невозможность взять кредит и застраховать риски (Куриков 2012; Пивнева 2019). Зависимость от государственной поддержки принципиально неустранима, что предъявляет большие требования к управлению отраслью и объемам вложений. Попытка создать зонтичную корпорацию для национальных предприятий в Югре провалилась в 2000-е гг, и уроки этой истории следовало бы разобрать отдельно, потому что у каждой смены управленцев округа встает задача по поддержке традиционного природопользования.

Отдельно, но коротко надо упомянуть экономические соглашениями родовиков с недропользователями, где местные органы власти выступают третьей стороной. В 2014 г. было охвачено 81\% субъектов права ТТП - это 3471 чел. на 263 ТТП. В масштабе всего округа эти выплаты пришлись на 11\% коренных жителей ХМАО, преимущественно из Сургутского и Нижневартовского районов. Западные районы почти не участвуют в этом процессе из-за малого перекрытия ТТП и промышленных объектов. Как следствие, уровень благосостояния родовиков в Югре очень различается по районам, внутри районов, и мало зависит от успехов в традиционном хозяйстве. Реестр субъектов права ТТП усилил диспропорции - это оказался “закрытый клуб” наследственных владельцев, закрепивший право, но не практику традиционного природопользования за узким кругом лиц. 


\section{Заключение}

Родовые угодья сработали в восточных районах, где промышленность получила мощный противовес в их виде. Главными адресатами Положения были восточные ханты, с сохранившимся стойбищным укладом жизни. В случае западных районов, где не было явной техногенной угрозы, а манси жили в поселках, родовые угодья не стали заметным феноменом. Заявителям сложно было обосновать родовое право, не хватало весомых причин, чтобы выделить угодья из совхозных или леспромхозных земель, особенно если эти предприятия обеспечивали их работой и были социально ответственны. С другой стороны, заявителей привлекала возможность приоритетного распоряжения биоресурсами, перспектива получения компенсаций в случае промышленного освоения. У тех, кто имел прямой доступ к информации и рычагам власти, путь к угодью был заметно короче. Администрации Березовского и Кондинского районов заняли осторожные позиции, замораживая без того неспешные бюрократические процедуры - неразборчивое одобрение заявок могло привести к серьезным конфликтам среди местных жителей за доступ к биоресурсам.

На заре 1990-х гг. предполагалось, что общины коренных народов получат контроль над ресурсами в зонах приоритетного природопользования (33\% округа), что позволило бы перезапустить традиционную экономику (неотрадиционализм). Но кризисы 1990-х гг. подкосили идею, требовавшую больших инвестиций и последовательной политики - родовые угодья не стали основой особых территориальных образований и политической власти, став лишь разновидностью земельной собственности. Из общей численности коренных жителей Кондинского и Березовского районов, непосредственно на угодьях сегодня проживает 0,2-0,4\%, демонстрируя потенциал такого образа жизни. Чуть больше доля сезонных пользователей угодьями; неизвестно число тех, кто пользуется, но не заявляет об этом и не является субъектом права. Скорее всего, все досягаемые угодья так или иначе используются, независимо от наличия прав на них.

Случаи успешных родовиков-общинников объясняются совокупностью предпринимательских навыков, разными видами экономической деятельности, союзом с чиновниками, продуктивностью угодий. Это всегда исключение из правила, которое заключается в том, что хозяйства на базе родовых угодий в рыночных условиях убыточны. Без товарных объемов добычи чего-либо, хорошей логистики, они потребляют больше средств, чем приносят. Интенсивность промыслов всегда упирается в ограниченность ресурсной базы, конъюнктуру рынка и непостоянство спроса на продукцию тайги. Владелец угодий остро нуждается в субсидиях, ссудах, программах поддержки, то есть постоянно должен взаимодействовать с различными агентами и инстанциями, чтобы держаться “на плаву”. Риски в подобных отношениях довольно высоки. Хозяйству требуются сторонние источники дохода, диверсификация занятий, наемный труд. К подобной деятельности коренные народы Севера только сейчас привыкают, число успешных предпринимателей в их среде невелико. К тому же правила меняются слишком часто, а федеральные законодатели так “закрутили гайки”, что сам институт родовых угодий в 2000-е гг. оказался под угрозой и более пятнадцати лет находился в правовом вакууме. «Хозяевами по факту мы так и не стали, два десятка лет утекло, а законодательство в сторону родовиков так и не повернулось. Скорее в обратную» (интервью, В.В. Бронников, с. Кондинское, 2017). 
Как итог владельцы угодий ориентируют детей на переезд в город, или другую сферу деятельности, а угодья держат “на всякий случай”.

Отчетливых перспектив развития у института родовых угодий (ТТП) в западных районах нет, чего нельзя сказать о традиционной экономике в целом. Лишь официальный ее сегмент находится в затяжном кризисе, вызванном отсутствием внятной стратегии со стороны государства и региона. Сам концепт родовых угодий за двадцать лет устарел: рост уровня жизни по-прежнему неразрывно связан с урбанизацией, и в этих условиях «лесную жизнь» сложно идейно обосновать, не обеспечив сопоставимый городу доход. Но объемы квот на традиционное природопользование едва дотягивают до уровня самообеспечения, промыслы забюрократизированы, а родовики недостаточно образованы для поиска иных сценариев развития и сторонних инвестиций. Все это кристаллизует малоперспективный сценарий выживания, сведения концов с концами. Чтобы угодье развивалось, необходимо товарное хозяйство, а для его появления - поддержка государства, упрощение и сокращение бюрократических процедур, институт страхования рисков и доверительная среда. Это требует перезагрузки всей системы отношений, поскольку сложившаяся среда исключает инициативы - слишком велик взаимный багаж упреков, обид и обманутых ожиданий.

\section{Благодарности}

Автор выражает признательность респондентам-родовикам Кондинского района ХМАО-Югры: Евгению Вахрушеву (Карым), Виктору Бронникову (Кондинское), Александру Кобылину, Николаю Нялину, Николаю Сургучеву из с. Болчары.

\section{Источники и материалы}

ААБР 1993-1994 - Архив администрации Березовского района. Ф. 72. Оп. 1. Д. 14. Документы /справки, карты территорий, информации, заключения/ по развитию традиционных отраслей, национальных общин. 1993-1994 гг.

ААБР 2001 - Архив администрации Березовского района. Ф. 72. Оп. 1. Д. 44. Документы (справки, отчеты, информации) по родовым общинам, по развитию традиционных отраслей хозяйствования, обеспечения занятости населения. 2001 г.

ГАХМАО 1994 - Государственный архив Ханты-Мансийского АО. Ф. 418. Оп. 1. Д. 51. Письма, заявления, обращения, жалобы граждан коренной национальности за 1994 г. (05.01.1994-26.12.1994).

ГАХМАО 1995 - Государственный архив Ханты-Мансийского АО. Ф. 418. Оп. 1. Д. 57. Доклады делегатов V съезда КМНС округа. Ханты-Мансийск, 7-8 июня 1995 г.

Функциональное 2012 - Функциональное зонирование территорий традиционного природопользования Нижневартовского и Сургутского районов Ханты-Мансийского автономного округа - Югры: отчет. Под рук. А.М. Брехунцова / ОАО «СибНАЦ». Тюмень, 2012 // Департамент недропользования и природных ресурсов ХМАО - Югры.

Функциональное 2015 - Функциональное зонирование территорий традиционного природопользования Белоярского, Березовского, Кондинского, Нефтеюганского, Октябрьского, Советского и Ханты-Мансийского районов Ханты-Мансийского автономного округа Югры: отчет. Под рук. М.А. Шумова / АО «Сибземпроект». Братск, 2015 // Департамент недропользования и природных ресурсов ХМАО - Югры. 


\section{Научная литература}

Вигет Э. Экономика и традиционное землепользование восточных хантов // Очерки истории традиционного землепользования хантов (материалы к атласу). Екатеринбург: Тезис. 2002. C. $167-222$.

Куриков В.M. Перспективы развития традиционных отраслей хозяйствования на территориях сельских поселений Югры // Вестник угроведения, 2012. Т. 2. № 4 (11). С. 147-154.

Кучинский М.Г. Риторика традиционности и реалии природопользования // Расы и народы. Современные этнические и расовые проблемы. Москва: Наука. Вып. 33. 2007. С. 58-88.

Логинов В.Г., Попков Ю.В., Тюгашев Е.А. Коренные малочисленные народы Севера, Сибири и Дальнего Востока: политико-правовой статус и социально-экономическое положение. Екатеринбург: Институт экономики УрО РАН, 2009. 138 с.

Мартынова Е.П. Традиционные отрасли хозяйства обских угров: современные адаптивные стратегии в рыночной экономике // Вестник угроведения, 2017. Том 31 (4). С. 119-130.

Мартынова Е.П. Аборигенное предпринимательство в Северном Приобье // Вестник антропологии, 2019. № 2 (46). С. 72-85.

Мартынова Е.П., Пивнева Е.А. Современное природопользование таежного населения Нижнего Приобья: Ханты-Мансийский и Октябрьский районы Ханты-Мансийского А.О. / Исследования по прикладной и неотложной этнологии ИЭА РАН. Документ № 130. М. 1999. 30 с.

Мартынова Е.П., Пивнева Е.А. Традиционное природопользование народов Северного Приобья (по материалам Ханты-Мансийского автономного округа). Москва: ИЭА РАН, 2001. 152 с.

Новикова Н.И. (отв. ред.). Люди Севера: права на ресурсы и экспертиза. М.: Издательский дом «Стратегия», 2008. $511 \mathrm{c.}$

Новикова Н.И. Охотники и нефтяники: Исследование по юридической антропологии. М.: Наука, 2014. 407 c.

Пахомов В.П., Игнатьева М.Н., Беляев В.Н., Логинов В.Г., Литвинова А.А., Пермяков А.И., Райшев А.И. Методические материалы по взаимоотношениям коренных малочисленных народов Севера с хозяйствующим субъектами. Екатеринбург: Институт экономики УрО PAH, 2000. $63 \mathrm{c}$.

Пивнева Е.А. «Сколько весит рыбий хвост?»: этничность и бюрократия в традиционном рыболовстве на Обском Севере // Вестник антропологии, 2019. № 2 (46). С. 86-102.

Пика А.И., Прохоров Б.Б. Неотрадиционализм на Российском Севере (этническое возрождение малочисленных народов Севера и государственная региональная политика). Ин-т народнохозяйственного прогнозирования РАН. М., 1994. 224 с.

Положение о статусе родовых угодий в Ханты-Мансийском автономном округе // Югра. 1992. № 3. С. 2-9.

Территории традиционного природопользования Ханты-Мансийского автономного округа Югры в период 1992-2004 гг. Информационный обзор. Екатеринбург: ООО «Изд. Дом Аква-Пресс», 2005. 170 с.

Федорова Е.Г. Национальные общины Средней Сосьвы и их создатели // Этнокультурное наследие народов Севера России. М.: ООО «Август Борг», 2010. С. 203-210.

Хакназаров С.X. Проблемы социально-экономического развития территорий традиционного природопользования коренных народов ХМАО-Югры (по материалам социоологических исследований). Ханты-Мансийск: Югорский формат, 2016. 100 с.

Харамзин Т.Г. Хайруллина Н.Г. Обские угры: социально-экономическая ситуация на пороге третьего тысячелетия (По материалам социологических исследований). Ханты-Мансийск: Полиграфист, 2000. 186 с.

Харамзин Т.Г. Экономика традиционного природопользования коренных народов Севера. Ханты-Мансийск, 2001. 294 с. 
Abramov, Ilya $V$.

\title{
'Territories of Traditional Nature Use' without Indigenous Users - Case of Western districts of Khanty-Mansi Autonomous Okrug - Yugra
}

\author{
DOI: $10.33876 / 2311-0546 / 2021-54-2 / 324-339$
}

The special land law for indigenous peoples of Yugra was written in 1992 and became a counterweight to the development of the oil and gas industry and the growing alienation of natural land. As early as 1989, a third of the Okrug's territory was reserved for indigenous land management. The «Regulation about the status of family lands in the Khanty-Mansi Autonomous Okrug» defined 'rodovye ugod'ya '(family lands) as a natural-territorial complex where indigenous people have historically led a traditional life. Family lands were regarded as the basis for traditional nature management, and a space for preserving the original culture. By 1999, 465 family lands had been allocated, taking up half of the Surgut and Nefteyugansk districts and a quarter of the Nizhnevartovsk district. These were the lands of the historical residence of the Hanty. In the west of Yugra, in the Kondinsky and Berezovsky districts (where the Mansi mostly lived), the family lands occupied 3.3 and $16.4 \%$ of the area. The article analyzes what caused the disproportions. On the example of the Kondinsky and Berezovsky districts, the economic and ethnic situation that determined the difference between the western and eastern parts is described. I mark the specific problems of allocating ancestral lands, the special decisions of the administrations, and the case of five family lands from the Bolchary village is separately analyzed. In 2001, the Regulation on Family Lands was absorbed by the Federal law on Territories of Traditional Nature Use. The article describes the difficulties that arose during the change of jurisdiction and discusses the disputed status of the owners (exrodoviki). The final legal status was obtained only after the functional zoning of the territories of traditional nature use (ex-family lands) in 2015. The result of the work was a set of special maps showing the exact boundaries, the size of forage and pasture zones, and the number of indigenous people permanently residing on the land. These data showed that in the western regions of the KhMAO-Yugra, the family lands did not fulfill their original task of creating reserves for original culture and traditional nature management. In 2014, less than 0.5\% of the indigenous population lived permanently on family lands, and their contribution to the traditional economy was insignificant. The article uses specific examples to analyze the reasons why the concept of traditional nature management turned out to be inoperable. The differences between the concept of traditional nature management created by the state and the realities of the existence of ancestral lands are shown.

Keywords: family lands, territories of traditional nature use, neotraditionalism, indigenous small-numbered peoples of the North, Hanty, Mansi, Yugra

For Citation: Abramov, I.V. 2021. 'Territories of Traditional Nature Use' without indigenous users - case of Western districts of Khanty-Mansi Autonomous Okrug - Yugra. Herald of Anthropology (Vestnik Antropologii) 2: 324-339.

\section{Author Info:}

Abramov, Ilya V. - Researcher, Institute of History and Archaeology Ural brunch of Russian Academy of Science (Ekaterinburg, Russian Federation). E-mail: ilya_abramov@list.ru 


\section{Refereces}

Fedorova, E.G. 2010. Nacionalnye obshhiny srednej Sosvy i ix sozdateli [National community middle Sosva and their creators]. In Etnokulturnoe nasledie narodov Severa Rossii. Ed. by E.A. Pivneva, 203-210. Moscow: OOO «Avgust Borg».

Kharamzin, T.G. 2001. Ekonomika traditsionnogo prirodopol'zovaniia korennykh narodov Severa [Traditional nature management of the native peoples of the North]. Khanty-Mansiisk.

Kharamzin, T.G. and N.G. Khairullina. 2000. Obskie ugry: sotsial'no-ekonomicheskaia situatsiia na poroge tret'ego tysiacheletiia (Po materialam sotsiologicheskikh issledovanii) [Ob Ugrians: socio-economic situation on the threshold of the third Millennium (based on sociological research)]. Khanty-Mansiisk: Poligrafist.

Khaknazarov, S.Kh. 2016. Problemy sotsial'no-ekonomicheskogo razvitiia territorii traditsionnogo prirodopol'zovaniia korennykh narodov KhMAO-Yugry (po materialam sotsioologicheskikh issledovanii) [Problems of socio-economic development of the territories of traditional land use of indigenous peoples of the Khanty-Mansiysk Autonomous Okrug - Yugra (based on sociological research)]. Khanty-Mansiisk: Iugorskii format.

Kuchinskii, M.G. 2007. Ritorika traditsionnosti i realii prirodopol'zovaniia [The rhetoric of tradition and the realities of nature]. Rasy i narody. Sovremennye etnicheskie i rasovye problemy. Vol. 33: 58-88.

Kurikov, V.M. 2012. Perspektivy razvitiya tradicionnyh otraslej hozyajstvovaniya na territoriyah sel'skih poselenij Yugry [Prospects of development of traditional economic sectors in the territories of rural settlements of Yugra]. Vestnik ugrovedeniya, 4 (11): 147-154.

Loginov V.G., Iu.V. Popkov and E.A. Tiugashev. 2009. Korennye malochislennye narody Severa, Sibiri i Dal'nego Vostoka: politiko-pravovoi status i sotsial'no-ekonomicheskoe polozhenie. Ekaterinburg: Institut ekonomiki UrO RAN.

Novikova, N.I. 2008. Ed. Liudi Severa: prava na resursy i ekspertiza [People of the North: rights to resources and expertise]. Moscow: Izdatel'skii dom «Strategiia».

Novikova, N.I. 2014. Oxotniki i neftyaniki: Issledovanie po yuridicheskoj antropologii [Hunters and oilmen: a study in legal anthropology]. Moscow: Nauka.

Martynova E.P. Aborigennoe predprinimatel'stvo v Severnom Priob'e [Aboriginal entrepreneurship in the Northern Ob region]. Vestnik antropologii. 2019. 2 (46): 72-85.

Martynova, E.P., Pivneva E.A. 2001. Tradicionnoe prirodopol zovanie narodov Severnogo Priob ya [Traditional nature management of the peoples of the Northern Ob region]. Moscow.

Pakhomov, V.P., M.N. Ignat'eva, V.N. Beliaev, V.G. Loginov, A.A. Litvinova, A.I. Permiakov and A.I. Raishev. 2000. Metodicheskie materialy po vzaimootnosheniiam korennykh malochislennykh narodov Severa s khoziaistvuiushchim sub"ektami [Methodological materials on the relationship of indigenous small-numbered peoples of the North with economic entities]. Ekaterinburg: Institut ekonomiki UrO RAN.

Pika, A.I., and B.B. Prokhorov. 1994. (eds.) Neotraditsionalizm na Rossiiskom Severe (etnicheskoe vozrozhdenie malochislennykh narodov Severa $i$ gosudarstvennaia regional'naia politika) [Neotraditionalism in the Russian North (ethnic revival of small-numbered peoples of the North and state regional policy)] Moscow: In-t narodnokhoziaistvennogo prognozirovaniia RAN.

Pivneva, E.A. 2019. "Skol'ko vesit rybii khvost?": etnichnost' i biurokratiia v traditsionnom rybolovstve na Obskom Severe ["How much does a fish tail weigh?": ethnicity and bureaucracy in traditional fishing in the Ob North]. Herald of Anthropology (Vestnik antropologii) 2(46): 86-102.

Territorii traditsionnogo prirodopol'zovaniia Khanty-Mansiiskogo avtonomnogo okruga - Iugry $v$ period 1992-2004 gg. Informatsionnyi obzor [Territories of traditional environmental management of indigenous peoples of the Khanty-Mansiysk Autonomous Okrug - Ugra in the period 1992-2004. Information review]. Yekaterinburg: OOO «Dom Akva-Press».

Viget E., 2002. Ekonomika i traditsionnoe zemlepol'zovanie vostochnykh khantov [Economy and traditional land use of the Eastern Khanty]. In Ocherki istorii traditsionnogo zemlepol'zovaniia khantov (materialy $k$ atlasu) [Essays on the history of traditional land use of the Khanty (materials for the Atlas)], 167-222. Yekaterinburg: Thesis. 